\title{
Maternal genealogies: the figure of the mother in/and literature
}

\section{Gill Rye}

Fell, Alison S. (2003) Liberty, Equality, Maternity in Beauvoir, Leduc and Ernaux (Oxford: Legenda, EHRC) x + 208 pp. ISBN 1-90075573-4 (pb).

Giorgio, Adalgisa (ed.) (2002) Writing Mothers and Daughters: Renegotiating the Mother in Western European Narratives by Women (New York and Oxford: Berghahn Books) xiv + 258 pp. ISBN 1-57181-341-1 (pb).

Goolcharan-Kumeta, Wendy (2003) My Mother, My Country: Reconstructing the Female Self in Guadeloupean Women's Writing (Oxford: Peter Lang) 240 pp. ISBN 3-906769-76-3 (pb).

Norman, Buford (ed.) (2000) The Mother in/and French Literature, French Literature Series XXVII (Amsterdam and Atlanta: Rodopi) xx + 233 pp. ISBN 90-4200710-9 (pb).

Santoro, Miléna (2002) Mothers of Invention: Feminist Authors and Experimental Fiction in France and Quebec (Montreal and Kingston: McGill-Queen's University Press) xvi + 348 pp. ISBN 0-7735-2487-8 (pb).

Mothers are everywhere in literature, especially, though not exclusively, in work by women writers. As Marianne Hirsch's seminal study The Mother/Daughter Plot (1989) demonstrates, the literary representation of mothers is complex and fraught with contradiction. Mother-daughter relations, Hirsch finds, are particularly ambivalent, as daughters (and writers) negotiate their way through 'the fluctuations of symbiosis and separation' (20) in their relationships with their mothers, in a quest for their own sense of self. Hirsch focuses on Western European and North American 
novels of the nineteenth and twentieth centuries, which she divides into three literary movements: realism, modernism and postmodernism. The recent crop of texts that are brought together in this review article for the Journal of Romance Studies, between them, engage with the representation of mothers (and, especially, of mother-daughter relationships) in a wide range of French and francophone literature and, in Adalgisa Giorgio's volume, across Western European literatures. Together, then, they supplement Hirsch's study, extending both the historical and cultural contexts and the theoretical paradigms of analysis, on the one hand, because they cut across the English and American literary movements that Hirsch employs, and, on the other, because they take in a wider sweep of literature in terms of both historical period and genre. Thus, they offer new insights into the representation of the mother-figure, and throw new light on relations with the mother in, and through the creation of, literature. $^{1}$

Not surprisingly, perhaps, feminist thinkers have produced most of the influential contemporary work on motherhood and especially on mother-daughter relationships. Indeed, motherhood has been a complex issue for feminism, and feminist debates throughout the twentieth century grappled with its contradictions, from women's relations with their mothers through to women's experiences as mothers. Motherhood is such an explosive topic because, as Nancy Chodorow argues in her classic work on 'the reproduction of mothering' (Chodorow 1978), it is so deeply embedded in our concepts of identity, in the construction of individual subjectivities and in the social organization of gender.

The texts for review here are thus situated - and, indeed, situate themselves in relation to an enormous body of feminist work, from both France and the U.S., on mothers, on motherhood, on mothering and on mothers and daughters. Simone de 
Beauvoir is a consistent point of reference. Buford Norman's volume collects together the proceedings of a conference, organized by Nancy Lane, which coincided with the fiftieth anniversary of the publication of Beauvoir's Le Deuxieme Sexe [The Second Sex], in which Beauvoir set out her renowned negative attitudes towards motherhood, and some of the contributions to the volume reflect that negativity in their analyses of mothers in literature (Norman 2000: xiv). U.S. feminist theorist and poet Adrienne Rich is also a seminal figure for the authors and editors reviewed here. Adalgisa Giorgio identifies in many of the essays in her volume a move from Rich's concept of matrophobia (the fear of becoming [like] the mother) (Rich 1976) to a more positive relation with the mother, or, at least, with her heritage, in a quest for the self. Rich's text is particularly influential for theorizing the differentiation between motherhood as institution (motherhood as determined by dominant discourses) and motherhood as practice (the experiences of individual women).

Psychoanalytically based feminist thinking in 1970s France has, over the years, made a significant contribution to feminist debates on motherhood, the work of Hélène Cixous, Luce Irigaray and Julia Kristeva being particularly influential. 'French feminism', however, has not been without its detractors, being criticized for its socalled essentialism and a-historical analysis (see, for example, Stanton 1986). ${ }^{2}$ It is striking, then, that, the texts reviewed here, which admirably ground their analyses of the mother in specific historical and cultural contexts, continue to draw heavily on the work of these thinkers. The particular strength and contemporaneity of their analyses lie in the fact that the most important concepts of 'French feminism' are brought into productive dialogue, explicitly or implicitly, with the work of a range of other theorists: for example, U.S. feminism (Fell, Giorgio), Quebec writers (Santoro), the 
work of Michel Foucault (Fell, Norman) and of a number of postcolonial theorists (Norman, Goolcharan-Kumeta).

Of the 'French feminists', Luce Irigaray is cited time and time again across the texts reviewed. Irigaray's work emphasizes the ways in which motherhood is entwined with women's subjectivity. She offers, on the one hand, a negative diagnosis of mother-daughter relations under patriarchy; for her, this relationship is based on rivalry and, indeed, matricide (as the woman in the mother is negated in favour of her maternal function) (Irigaray 1981). On the other hand, Irigaray's work also has a positive forward-looking impetus; as a 'philosopher of change' (Whitford 1991), she maintains that the mother-daughter relationship must - and can be - be fundamentally re-imagined, in order to allow new possibilities for women's subjectivity (Irigaray 1981, 1986). Irigaray's work is sometimes criticized as utopian, as not attending to socio-cultural or historical specificity, or as emphasizing sexual difference at the expense of other differences, such as those of class, ethnicity and sexuality (see, for example, Moi 1991). Such critiques may omit to take account of Irigaray's important breadth of vision and of the impressive range of cultural fields across which she is envisioning, and working for, change: language and socio-linguistics; European law; politics; education; myth and psychoanalysis; religion; philosophy; architecture.

Kristeva's work is likewise a principal reference point, in particular her early essays on representations of maternity in relation to the Virgin Mary (Kristeva 1977, 1983). What is rarely recognized, however, is that Kristeva has continued to write about motherhood in a variety of contexts, from a novel (Kristeva 1996) and an epistolary co-authored essay with anthropologist Catherine Clément (Clément, Kristeva 1998) to a three-volume study of female genius in the twentieth century (Kristeva 1999, 2000, 2002). Indeed motherhood is an ongoing theme of Kristeva's 
oeuvre, concerned as she is with the different types of crisis that threaten the modern subject. Kristeva's perspective is important, because, although she does emphasize the role of the mother (as the maternal function of psychoanalysis) in the formation of the psyche and identity of the individual, she does not omit to theorize motherhood from the point of view of the woman as mother.

The attention to Kristeva's early work over her later contributions to the motherhood debate is emblematic of the lack of use made in feminist criticism of more recent French theoretical work on motherhood. While, in addition to Kristeva and Irigaray, Annie Leclerc's celebration of motherhood (Leclerc 1974), Élisabeth Badinter's deconstruction of the maternal myth (Badinter 1980) and Christiane Olivier's psychoanalytical account (Olivier 1980) are landmark texts, very few later texts are referred to. Indeed French theoretical production on motherhood over the last two decades has been rather patchy, in both output and quality. In contrast, a great deal of Anglo/American work on motherhood produced during the period has continued to fuel the feminist debate.

If Hirsch's The Mother/Daughter Plot identifies, above all, a series of highly ambivalent mother-daughter relationships, it also points to the tentative emergence of a maternal subjectivity in contemporary Western literature. For the most part, Hirsch's analyses find that mother/daughter plots over the last two centuries tend to negate the subjectivity of the mother in favour of that of the daughter. Mothers in the fiction she analyses are, overwhelmingly, objects of their daughters' narratives, rather than subjects of their own: 'To speak for the mother, as many of the daughters [...] do, is at once to give voice to her discourse and to silence and marginalize her' (Hirsch 1989: 16). In attempting to give voice to the mother, daughters (narrators, writers) are very often involved in a complex tension between 'identification and 
distanciation, recognition and appropriation' (16). Only in the section on postmodern fiction does Hirsch identify a burgeoning maternal subjectivity, in particular in the work of Black American writers like Toni Morrison and Alice Walker, who, Hirsch points out, "clearly identify themselves as a new feminist generation in relation to the maternal tradition of the past, writers for whom fathers, brothers, and husbands occupy a less prominent place, writers who are in a more distant relation to cultural and literary hegemony' (16).

In Alison Fell's Liberty, Equality, Maternity, mothers are very much still objects of discourse. Fell considers motherhood in the work of three twentieth-century writers (Beauvoir, Violette LeDuc and Annie Ernaux). This volume offers a fascinating analysis of motherhood as represented by these three writers but it is particularly valuable and important for its historicization of motherhood in the specific context of the French Republic. As Fell's title suggests, here mothers are "custodians of [...] "Frenchness"' (2); mothers, and their cultural representations, are bound up with France's political and cultural image and, above all, with its economic prosperity. Fell draws on Foucault to analyse the historically specific discourses that have been brought to bear on motherhood in twentieth-century France: pronatalism, from the depopulation of WW1 and France's survival as a nation (43), through WWII and Vichy's motto 'travail, famille, patrie' (53) ['work, family, country'], to the postwar baby boom (59); family planning and the legalization of contraception and, in 1979, abortion (71); and late twentieth-century feminism, when motherhood finally becomes a choice for women, and medical and legal developments bring about a 'more fluid understanding of maternity and of the family' (74) and contribute to women's changing aspirations. 
In this optic of 'circulating, competing, historically specific motherhood discourses' (Fell 2003: 9), Fell shows how the three writers produce, on the one hand, 'a public maternal narrative', and, on the other, the narrative of a 'conflictual "private" mother-daughter relationship) (11) that are in tension with each other. While all three writers critique bourgeois norms and challenge the dominant pronatalist discourses of their respective times, each of them also reveals an 'ambiguous private maternal narrative' which destabilizes their writing $(103,106,150,179)$. Ultimately, Fell considers Beauvoir and LeDuc to be attempting to "write" their mothers out of their lives (or, perhaps, their lives out of their mothers)' and Ernaux to be concerned with writing her mother into hers (156). Fell also analyses the narrator's own disillusionment with bourgeois motherhood in Ernaux's La Femme gelée (1981) [The Frozen Woman], interpreting it as an attack on 1960s and 1970s models of femininity and the 'superwoman' discourse, in which feminist discourses on women's equal opportunities clash with traditional concepts of the family (Fell 2003: 160-1).

Fell is one of the contributors to Buford Norman's collection too, comparing, here, the representation of the mother's body in Beauvoir and Ernaux. This edited volume brings together a wide range of work on motherhood in French and francophone literature (and one on African francophone cinema) from the seventeenth to the twentieth century. The contributions are of varying length, the major being Domna Stanton's keynote paper, which focuses on Mme de Sévigné's 'excessive love' for her daughter (Norman 2000: 14). Here, Stanton explicitly situates her historically and ideologically specific analysis in relation to her earlier critique of the a-historicism of French feminism (Stanton 1986). Other contributions on seventeenthcentury culture include Holly Tucker on representations of pregnancy in fairy tales and Deborah J. Hahn on mothers and sexuality in comic theatre. 
Norman's collection is the only one of the texts reviewed to include analyses of the mother in texts by male authors: Stendhal (by Eric du Plessis); Maupassant (by Philip G. Hadlock); Gide (by Kimberly Philpot van Noort) and Lamartine (by Aimée Boutin). Boutin analyses Lamartine's publication of his mother's diary, which seems to give voice to the mother, but which is in fact revised, edited and commentated by the son, in what Boutin calls 'reverse gestation' (135). The result is a text that focuses almost entirely on the mother's relationship with her son, to the exclusion of her relationship with her five daughters.

If Lamartine's text represents, in Boutin's analysis, a son's valorization of his own sense of self, many of the contributors to Norman's volume, like Hirsch (1989) and other of the authors reviewed here, discuss the mother in relation to the daughter's quest for identity. Claire-Lise Tondeur considers intergenerational genealogies in the work of three twentieth-century Swiss writers, in which motherdaughter relations are all problematic, but which each results in different outcomes: 'un naufrage identitaire' ['identity as shipwreck'], 'une separation vécue comme un libération' ['separation lived as liberation'] and 'l'essor d'un futur écrivain' [the blossoming of a future writer'] (Norman 2000: 155). Daniela Di Cecco's contribution focuses on adolescent novels in France and Quebec. Here mothers play a central role in daughters' quests for identity, the father being either absent or in the background. Di Cecco draws on Terri Apter's work, which suggests that the development of the daughter's identity rests on the renegotiation of the mother-daughter relationship rather than on separation per se (Apter 1990). For Apter, the adolescent daughter needs to elicit from her mother recognition of her developing self, and thus conflict is productive rather than problematic, in a similar way, perhaps, to Jessica Benjamin's 
concept of intersubjectivity in which some degree of conflict between mother and child is positive for both individual subjectivities (Benjamin 1990).

In the same volume, Cecilia Beach analyses plays by Guadaloupean francophone writer, Maryse Condé. Here, the main themes relate to migration: dislocation, alienation, wandering, exile. In Condé, Beach identifies the association of the mother with the motherland, as does Wendy Goolcharan-Kumeta's My Mother, My Country, which is devoted to Guadeloupean women's writing. GoolcharanKumeta's own examples are novels, published between 1960 and 1982, by Condé, Myriam Warner-Vieyra, Michèle Lacrosil, Jacqueline Manicom and Simone Schwartz-Bart. The chosen texts are 'fictional autobiographies' (28-30), in which mother-daughter relations are a dominant theme and in which the quest for identity is, above all, lived as a crisis. In these novels, the relation with the mother is, on the whole, unresolved, and the narratives reveal stories of exile, of alienation and of the disintegration of the self. Here the personal lives of the characters reflect the political history of the island, Guadaloupe's postcolonial assimilation to France as a department d'outre-mer [overseas department] and alienation from its own cultural and linguistic identity. Mother-figures mirror motherlands (Guadeloupe, Africa, France) as women, who are torn between the dual socio-cultural systems of the French Caribbean situation, search for alternatives to their bad, absent or rejecting biological mothers. Only in Schwartz-Bart's Pluie et vent sur Télumée Miracle (1972) [The Bridge of Beyond], the subject of Chapter 6, is a more positive outcome to be found. This novel builds on a women-centred Caribbean experience to valorize matrilineal transmission and a maternal genealogy, although, significantly, this is developed through substitute rather than biological mothers. Some of the theorizing in Goolcharan-Kumeta's volume is rather under-developed and the analysis could be 
more nuanced at times, but the work is especially interesting for, on the one hand, its particular focus on Guadeloupean writers, and, on the other, its attention to the breadth of situations within the Guadeloupean context itself; for example, Chapter 4 deals with the complexity of the caste system, and Chapter 5 with a heroine of East Indian descent, as opposed to the Afro-Caribbean characters of the other chapters. Ultimately, for Goolcharan-Kumeta, the postcolonial women writers of her study are concerned with creating - or reconstructing - the female self through a range of mother substitutes. The emergent maternal subjectivities that Hirsch found in writers from cultures with a strong maternal tradition are, however, nowhere to be found.

Adalgisa Giorgio's very useful volume, Writing Mothers and Daughters, provides a valuable cross-cultural context for the study of the mother-daughter relationship in literature. Following the editor's introduction and strong theoretical chapter, individual chapters are devoted to a different Western European literature: Spanish, Irish, Italian (also by Giorgio), French, English plus German and Austrian. The chapters function as overviews and thus each covers multiple texts; the historical spread is generally postwar although the Italian and English contributions focus specifically on the last two decades of the twentieth century. In her introduction, Giorgio identifies some common trends, but also emphasizes the uniqueness of the individual mother-daughter relationships analysed, 'with the familial and experiential circumstances in which their protagonists are enmeshed impinging upon - and being impinged upon by - the psychic substratum as well as social and cultural structures' (Giorgio 2002: 6). Her theoretical chapter (Chapter 1) also provides very useful statistics on European birth rates, abortion rates, social policies, family patterns and the ethics of reproductive technologies. Here, as elsewhere in the texts under discussion, new technologies and medical developments are rightly considered to be 
forcing a re-examination of the maternal function and of 'the concepts of motherhood and parenting at many levels' (35).

The individual chapters in Giorgio's volume, investigating the representation of mothers and daughters in national literatures and with respect to their respective national cultures and histories, attest to a vast array of different treatments. The chapter on Spanish narrative (by Christine Arkinstall) gallops through a number of themes and 'alternative scripts' for mothers and daughters, drawing, as do many of the chapters, on Irigaray's call for the mother-daughter relationship to be resymbolized. The chapter on Irish fiction (by Anne Fogarty) considers a wide range of texts and approaches to the mother, concluding that if alternative views are identifiable, they are nonetheless still problem-laden (85-6). Giorgio's own chapter on contemporary Italian narrative relates literary examples to the changing attitudes to motherhood in Italy, which now has the lowest birth rate in Europe (149).

Alex Hughes's discussion of the French context also covers multiple texts but charts a clear and useful trajectory through twentieth-century women's writing: from ambivalent mother-daughter relations in Beauvoir and LeDuc, through the texts of Duras and Marie Cardinal, in which the relationship is inflected by a colonial environment (164-72), to a range of contemporary writing - Ernaux, beur author Djura and Marie Redonnet (for an imagined alternative maternal genealogy). The chapter on the contemporary English novel (by Paola Splendore) covers a wide range of texts and themes, as does that on postwar German and Austrian literature (by Chris Weedon), with which the volume concludes. Here, Weedon identifies several trends: the recovery of history; abusive mothers; the socio-cultural significance of motherdaughter relationships; and the internal dynamics of the nuclear family. 
While most of the contributions to Writing Mothers and Daughters arguably attempt to cover too much individually, together they provide a fascinating comparative view of the way the figure of the mother is being represented in Western European literature, and the volume as a whole is a valuable reference point for future research.

Miléna Santoro's Mothers of Invention takes a somewhat different approach from the other texts reviewed here. Hers is a study of four women writers of the 1970s whom she posits as "literary "foremothers" (Santoro 2002: 6), in the sense of a feminist avant garde: Cixous and Jeanne Hyvrard, working in France, and Madeleine Gagnon and Nicole Brossard in Quebec. Santoro aims to sidestep the 'theoretical skirmishes' and 'reductive view' of French feminism (4), in order to concentrate on fiction writing by these authors, highlighting the experimental strategies of their texts, especially with reference to both literal and metaphorical maternity, which is a common, important and, indeed, ongoing theme in their work.

After a historical contextualization of 1970s feminism in France and Quebec, Santoro devotes one chapter to each author and, apart from the chapter on Hyvrard, concentrates on just one text per chapter. The result - and this is where the real strength and value of this volume lies - is a highly detailed and sensitive close reading of what are now classic texts by the four writers: Cixous's $L a$ (1976) [The Feminine One/La]; Gagnon's Lueur (1979) [Light]; L'Amèr ou le chapitre effrité (1977) [These Our Mothers, or The Disintegrating Chapter] by Brossard; and Hyvrard's first three novels. By means of a fine literary analysis which attends closely to language and linguistic play, genre, form, intertextuality, metaphor and associations in the texts, Santoro concludes that, whereas Cixous and Gagnon focus on the maternal as a positive site of creativity, in 'a subversive relation to literary and linguistic traditions' 
(152), Brossard and Hyvrard reject the mother 'as part and parcel of the same set of repressive traditions and conventions' (152). Thus their writing exemplifies the polarized nature of the debate on motherhood of the time. Santoro is keen to emphasize the reciprocal connections of the writers' work; the flow of influence is not unidirectional, from metropole to the margins, from France to Quebec, but rather works as a cross-fertilization between them. However, as she readily admits, the 'maternal' status that she claims for these writers does not mean that a genealogy of similar literature can be traced through identifiable literary 'daughters'. Rather, she defines their heritage in terms of Jaussian "literary "horizons of expectation" (279) that have laid the terrain for the wealth of French and francophone women's writing that has been published over the last two decades.

Santoro's focus on the literariness of the work of her chosen authors here, albeit taken to a formidable level in her volume, is also echoed in the other texts reviewed. Although, between them, they draw on a wide range of theoretical models in order to analyse representations of the mother, none of them neglects textual analysis and, indeed, they all attest to the richness of the broad scope of literature analysed.

As Nancy Lane states in her introduction to The Mother in/and French Literature collection, 'the mother is a universal figure' (ix), but the books grouped together here are, above all, significant for their grounding of the figure of the mother in specific historical and cultural contexts, as well as in individual relationships and psychical formations. Repeatedly, though, representations of, and relations with, the mother in literature are interpreted as ambivalent. However, conflict does not always have a negative outcome. While many of the representations of mother-daughter relationships here render the daughters in crisis or alienated, as many literary texts 
portray positive negotiations with a maternal heritage, and maternal genealogies of different kinds are formed with mothers, grandmothers or surrogate mother-figures. And, undoubtedly, many of the texts analysed in the volumes reviewed are themselves the fruit of mother-daughter conflicts. As Giorgio aptly puts it: 'the rich corpus of narratives analysed [...] proves that if the dark continent of the mother-daughter relationship is not completely lit up, at least it is being explored, and in increasingly greater depth' (34).

Most striking is that, across all the texts reviewed, very few analyses focus on mothers from the point of view of the mother herself. As in Hirsch's study, mothers are overwhelmingly objects of others' discourses rather than subjects of their own. And, yet, narratives of mothering, by mothers, are, increasingly, to be found in contemporary women's writing. The work of analysing them, however, is, largely, still waiting to be done.

\section{Notes}

1 Of course, many other contemporary studies of motherhood in literature exist. Those particularly relevant to the context of this article include Cairns (1992); Corbin (1996); Hughes (1994); Saint-Martin (1999). 
2 I have enclosed 'French feminism' in inverted commas here because, as Christine Delphy (1995) rightly points out, other currents of feminism exist in France. Delphy argues that 'French feminism' is actually both a term and a concept coined by AngloAmerican academic feminists. Nonetheless, I continue to use it here as a shorthand to designate French psychoanalytically based feminist theory, or what is also sometimes known as 'difference feminism'.

\section{Works cited}

Apter, Terri (1990) Altered Loves: Mothers and Daughters during Adolescence (New York: John Wiley \& Sons).

Badinter, Élisabeth (1980) L'Amour en plus: histoire de l'amour maternel (XVIIe-Xxe siècle) (Paris: Flammarion).

Beauvoir, Simone de (1949) Le Deuxième Sexe (Paris: Gallimard).

Benjamin, Jessica (1990) The Bonds of Love: Psychoanalysis, Feminism, and the Problem of Domination (London: Virago).

Cairns, Lucille (1992) Marie Cardinal: Motherhood and Creativity (Glasgow: University of Glasgow French and German Publications).

Chodorow, Nancy (1978) The Reproduction of Mothering: Psychoanalysis and the Sociology of Gender (Berkeley and London: University of California Press).

Clément, Catherine, Julia Kristeva (1998) Le Féminin et le sacré (Paris: Stock).

Corbin, Laurie (1996) The Mother Mirror: Self-Representation and the MotherDaughter Relation in Colette, Simone de Beauvoir and Marguerite Duras (New York and Washington: Peter Lang). 
Delphy, Christine (1995) 'The invention of French feminism: an essential move', Yale French Studies 87, 'Another look, another woman: retranslations of French feminism', 190-221.

Hirsch, Marianne (1989) The Mother/Daughter Plot: Narrative, Psychoanalysis, Feminism (Bloomington and Indianapolis: Indiana University Press).

Hughes, Alex (1994) Violette LeDuc: Mothers, Lovers and Language (London: W. S. Maney \& Sons).

Irigaray, Luce (1981) Le Corps-à-corps avec la mere (Montreal: Éditions de la pleine lune).

(1986) 'Femmes divines', in Cross-References, Modern French Theory and the Practice of Criticism, ed. David Kelly and Isabelle Llasera (Society for French Studies, Supplementary Publications 8), 136-47.

Kristeva, Julia (1977) ‘Maternité selon Giovanni Bellini’ [1975], in Polylogue (Paris: Seuil), 409-36.

— (1983) 'Stabat Mater' [1976] in Histoires d'amour (Paris: Denoël), 295-327.

(1996) Possessions (Paris: Fayard).

(1999) Le Genie feminin, I: Hannah Arendt (Paris: Fayard). (2000) Le Genie feminin, II: Mélanie Klein (Paris: Fayard). (2002) Le Genie feminin, III: Colette (Paris: Fayard).

Leclerc, Annie (1974) Parole des femmes (Paris: Grasset \& Fasquelle).

Moi, Toril (1991) [1985] Sexual/Textual Politics: Feminist Literary Theory (London and New York: Routledge).

Olivier, Christiane (1980) Les Enfants de Jocaste: l'empreinte de la mère (Paris: Denoël/Gonthier). 
Rich, Adrienne (1976) Of Woman Born: Motherhood as Experience and Institution (New York: Norton).

Saint-Martin, Lori (1999) Le Nom de la mere: mères, filles et écriture dans la literature québècoise au feminine (Montreal: Éditions Nota Bene).

Stanton, Domna C. (1986) 'Difference on trial: a critique of the maternal metaphor in Cixous, Irigaray, and Kristeva', in The Poetics of Gender, ed. Nancy K. Miller (New York: Columbia University Press), 157-82.

Whitford, Margaret (1991) Luce Irigaray: Philosophy in the Feminine (London: Routledge). 